\title{
Targeting GLI1 Suppresses Cell Growth and Enhances Chemosensitivity in CD34+ Enriched Acute Myeloid Leukemia Progenitor Cells
}

\author{
Bing Longa,b,c Le-Xun Wang ${ }^{c}$ Fei-Meng Zhenga,d Shu-Ping Laib Duo-Rong Xu ${ }^{\mathrm{b}}$ \\ Yuan Huc Dong-Jun Lin ${ }^{c}$ Xiang-Zhong Zhang ${ }^{c}$ Lin Dong $^{d} \quad$ Zi-Jie Long ${ }^{c}$ \\ Xiu-Zhen Tong ${ }^{\mathrm{b}}$ Quentin Liü, ${ }^{\mathrm{a}, \mathrm{d}}$ \\ aState Key Laboratory of Oncology in South China, Cancer Center, Sun Yat-sen University, Guangzhou, \\ bDepartment of Hematology, The First Affiliated Hospital, Sun Yat-sen University, Guangzhou, \\ 'Department of Hematology, The Third Affiliated Hospital, Sun Yat-sen University, Guangzhou, \\ IInstitute of Cancer Stem Cell, Cancer Center, Dalian Medical University, Dalian, China
}

\section{Key Words}

Acute myeloid leukemia - Leukemia progenitor cell • Hedgehog signaling pathway • GLI1 • Small-molecule inhibitor • GANT61

\begin{abstract}
Background/Aims: Resistance of leukemia stem cells (LSCs) to chemotherapy in patients with acute myeloid leukemia (AML) causes relapse of disease. Hedgehog (Hh) signaling plays a critical role in the maintenance and differentiation of cancer stem cells. Yet its role in AML remains controversial. The purpose of the present study is to investigate the role of GLI1, the transcriptional activator of $\mathrm{Hh}$ signaling, in $\mathrm{AML}$ progenitor cells and to explore the anti-AML effects of GLI small-molecule inhibitor GANT61. Methods: The expression of GLI1 mRNA and protein were examined in AML progenitor cells and normal cells. The proliferation, colony formation, apoptosis and differentiation of AML progenitor cells were also analyzed in the presence of GANT61. Results: Kasumi- 1 and KG1a cells, containing more CD34+ cells, expressed higher level of GLI1 compared to U937 and NB4 cells with fewer CD34+ cells. Consistently, a positive correlation between the protein levels of GLI1 and CD34 was validated in the bone marrow mononuclear cells (BMMC) of AML patients tested. GANT61 inhibited the proliferation and colony formation in AML cell lines. Importantly, GANT61 induced apoptosis in $\mathrm{CD}_{34}{ }^{+}$enriched Kasumi-1 and KG1a cells, whereas it induced differentiation in U937 and NB4 cells. Furthermore, GANT61 enhanced the cytotoxicity of cytarabine (Ara-c) in primary CD34+ AML cells, indicating that inhibition of GLI1 could be a promising strategy to enhance chemosensitivity. Conclusions: The present findings suggested that Hh signaling was activated in AML progenitor cells. GLI1 acted as a potential target for AML therapy.
\end{abstract}




\section{Introduction}

Acute myeloid leukemia (AML) is a heterogeneous disease with poor overall clinical outcome. Although clinical advances in AML have been achieved, disease relapse remains an unsolved problem $[1,2]$. Leukemia stem cells (LSCs), which give rise to leukemic blasts, are resistant to therapy and responsible for disease relapse $[3,4]$. Thus, new approaches that target LSCs are needed.

The Hedgehog ( $\mathrm{Hh})$ signaling pathway is an evolutionarily conserved developmental pathway which regulates cell proliferation, migration and differentiation during embryonic development $[5,6]$. In the absence of $\mathrm{Hh}$, Patched (PTCH) suppresses the activity of Smoothened (SMO) by preventing its localization to the cell surface. Hh pathway is activated when Hh ligand binds to PTCH, relieving its inhibition on SMO and leading to activation of GLI family transcription factors (GLI1, 2, 3), which translocate to the nucleus to regulate the transcription of Hh target genes [7-10]. Among the GLI family members, GLI1 acts as both a transcriptional activator and a Hh target gene [11]. Importantly, GLI1 is regarded as the most reliable indicator for Hh pathway activation [12].

The deregulation of $\mathrm{Hh}$ signaling has been linked to the development of hematologic malignancies [13-15]. Current studies suggested that Hh signaling contributed to tumor maintenance, growth and resistance to chemotherapy in hematopoietic neoplasms, including diffuse large B-cell lymphoma and myeloid leukemia [16, 17]. In addition, Hh signaling participated in cancer stem cells (CSCs) survival and expansion in multiple myeloma (MM), chronic myeloid leukemia (CML) and acute leukemia. For example, the CSCs of MM expressed higher levels of Hh components than the mature plasma cells [18]. Inhibition of Hh pathway by SMO inhibitor cyclopamine efficiently targeted CML stem cells in vitro as well as in vivo $[19,20]$. Recent studies also reported that Hh signaling was activated in AML, and that inhibition of Hh signaling induced apoptosis and reduced drug-resistance in AML cells [21]. However, it still remained unclear whether Hh signaling was important for the maintenance of leukemia progenitor cells in AML.

Recently, Hh signaling pathway inhibitors, such as SMO and GLI inhibitors, have drawn great attention. For example, cyclopamine was found to be a potent inhibitor of SMO with anti-tumor activity in vitro and in vivo system [7]. In light of mounting evidence that $\mathrm{Hh}$ pathway activation occurred downstream of SMO, inhibitors that affected downstream of SMO, such as specific GLI inhibitors [22-24], are urgently required. GANT61, a GLI inhibitor, blocked GLI function and inhibited tumor cell growth in a GLI-dependent manner [25]. Recent studies demonstrated that GANT61 effectively induced cell death in colon carcinoma, neuroblastoma and chronic lymphocytic leukemia cells [26-28].

In this study, we showed that GLI1 was overexpressed in CD34 $4^{+}$subpopulation of AML cells. GLI1 inhibitor GANT61 induced AML cells apoptosis and differentiation. Moreover, combination of GANT61 with chemotherapeutics displayed a synergistic anti-proliferative effect on primary CD34 ${ }^{+}$AML cells. Thus, our study provided the evidence that targeting GLI1 could be a novel strategy for AML treatment.

\section{Materials and Methods}

\section{Materials}

GANT61 (ENZO) and Vismodegib (Selleck) was dissolved in dimethyl sulfoxide (DMSO) in a $10 \mathrm{mM}$ stock solution and stored at $-20^{\circ} \mathrm{C}$. Cytarabine (Ara-c) was purchased from Pfizer AB (Sollentuna) and was dissolved in DMSO in a $1 \mathrm{mM}$ stock solution and stored at $-20^{\circ} \mathrm{C}$.

Cell lines and cell culture

KG1a and Kasumi-1 cell lines were obtained from Deutsche Sammlung von Mikroorganismen and Zellkulturen GmbH (DSMZ) (Braunschweig) and cultured in RPMI 1640 medium (Gibco) supplemented 


\section{Cellular Physiology Cell Physiol Biochem 2016;38:1288-1302 \begin{tabular}{ll|l} 
and & DOI.1159/000443075 & $\begin{array}{l}\text { O 2016 S. Karger AG, Basel } \\
\text { www.karger.com/cpb }\end{array}$ \\
\hline
\end{tabular}}

Long et al.: GANT61 Enhances Chemosensitivity in AML

with $20 \%$ fetal bovine serum (FBS, Hyclone). According to immunological studies by DSMZ and others, KG1a and Kasumi- 1 cells are characterized by high fraction of CD34+ early progenitor cells [29, 30]. U937 and NB4 cell lines were obtained from the American Type Culture Collection (ATCC) and were cultured in RPMI 1640 medium supplemented with 10\% FBS. Following informed consent and in accordance with the approval of the Institutional Review Boards, primary clinical specimens were obtained from patients with newly diagnosed AML and healthy donors. Bone marrow mononuclear cells (BMMCs) were enriched by FicollHypaque (MP Biomedicals) density gradient centrifugation. Primary AML CD34 ${ }^{+}$and normal $\mathrm{CD}_{3} 4^{+}$cell separation were conducted by using a Magnetic activated cell sorting (MACS) CD34 MicroBead kit (Miltenyi biotech). Over $90 \%$ of the enriched cells were $\mathrm{CD}^{+} 4^{+}$as confirming by fluorescence activated cell sorting (FACS, Beckman) analysis.

\section{Cell viability assay}

Cell viability was assessed by WST-8 assay (Dojindo). Cells $\left(1 \times 10^{4} / \mathrm{ml}\right)$ were seeded in 96 -well plates and treated with indicated concentrations of reagents for $48 \mathrm{~h}$. Then, $10 \mu \mathrm{l}$ WST- 8 solution was applied to each well. Cells were incubated at $37^{\circ} \mathrm{C}$ for another $4 \mathrm{~h}$. The absorbance was measured at $450 \mathrm{~nm}$ by using a multi-well plate reader (Bio-Rad Microplate Reader).

\section{Lentiviral production and transduction}

Lentiviral short hairpin RNA (shRNA) plasmid (Gene Pharma) targeting GLI1 and the nontargeting control were transfected into 293T cells using Lipofectamine 2000 Reagent (Invitrogen). The viral supernatants containing GLI1 shRNA and control shRNA were used to infect Kasumi-1 and U937 cells. The shRNA sequences were as follows: GLI1 (ACCATTACGAGCCTCATTC) and control (GCAAGCTGA CCCTGAAGTT).

\section{Colony-forming assay}

Cells were cultured in RPMI 1640 medium supplemented with 0.9\% methylcellulose (Sigma) and 10\% FBS at $37^{\circ} \mathrm{C}$ in $5 \% \mathrm{CO}_{2}$. The colonies (containing 40 or more cells) were counted under light microscopy after 14 days culture.

\section{Wright-Giemsa staining}

Morphological signs of differentiation were detected by Wright-Giemsa staining. Cells were treated with GANT61 and/or ATRA for $96 \mathrm{~h}$. Smears of control and GANT61 and/or ATRA treated cells were stained with Wright-Giemsa solution for $25 \mathrm{~min}$, rinsed with distilled water and air dried. Cell morphology was studied by light microscopy.

\section{Sub-G1 population assay}

Single-cell suspensions were fixed in ice-cold 70\% ethanol, labeled with propidium iodide (PI, $50 \mu \mathrm{g} /$ $\mathrm{ml}$, Sigma) for at least $15 \mathrm{~min}$ in dark at $37^{\circ} \mathrm{C}$ and analyzed directly on a FAC Scan as described [31].

\section{Measurement of apoptosis by Annexin V/PI analysis}

After collecting and washing twice with PBS, GANT61 treated and untreated cells were resuspended in the binding buffer $(500 \mu \mathrm{l})$. FITC-Annexin-V $(5 \mu \mathrm{l})$ was added to the cells followed by addition of $5 \mu \mathrm{l}$ PI according to the protocol of the Annexin V-FITC/PI kit (EMD Biosciences). The samples were then incubated for $15 \mathrm{~min}$ in the dark and subjected to flow cytometry evaluation.

Quantitative real-time PCR ( $q R T-P C R)$

Total RNA was extracted with Trizol isolation reagent (Invitrogen). Reverse transcription was performed by using a reverse transcriptase first strand cDNA synthesis kit (Invitrogen). PCR was performed with Platinum ${ }^{\circledR}$ SYBR $^{\circledR}$ Green qPCR SuperMix (Invitrogen) as recommended by the manufacturer. The primers used were listed in Table 1. GAPDH was used as the internal control.

Immunocytochemical staining

Primary leukemia blasts and normal BMMCs were washed with phosphate buffered saline and smeared glass slides by cytospin. The slides were fixed and incubated in $\mathrm{H}_{2} \mathrm{O}_{2}$, blocked with $1 \%$ bovine serum 


\begin{tabular}{|c|c|}
\hline Cellular Physiology & Cell Physiol Biochem 2016;38:1288-1302 \\
\hline and Biochemistry & \begin{tabular}{l|l} 
DOI: 10.1159/000443075 & $\begin{array}{l}\text { O 2016 S. Karger AG, Basel } \\
\text { www.karger.com/cpb }\end{array}$ \\
Published online: March 24, 2016 &
\end{tabular} \\
\hline
\end{tabular}

Table 1. Primer sequences for the Real-time PCR assay

\begin{tabular}{lll}
\hline Name & Forward $5^{\prime} \rightarrow 3^{\prime}$ & Reverse 5 $^{\prime} \rightarrow 3^{\prime}$ \\
\hline GLI1 & TTGGAGAAGCCGAGCCGAGTATC & GAGTAGACAGAGGTTGGGAGGTAAGG \\
GLI2 & GCTGGCTGACCTCAAGGAAGAT & CCGTGGATGTGCTCGTTGTTG \\
GLI3 & GGACGCTGATGCCAACCTGAA & CGGAGCTGACTTCGTTCCACTG \\
SMO & TGGTCACTCCCCTTTGTCCTCAC & GCACGGTATCGGTAGTTCTTGTAGC \\
PTCH1 & TTCCAGTTAATGACTCCCAAGCAAATG & GCGACACTCTGATGAACCACCTC \\
GAPDH & GGAGCGAGATCCCTCCAAAAT & GGCTGTTGTCATACTTCTCATGG \\
\hline
\end{tabular}

albumin (BSA), and incubated with rabbit anti-GLI1 antibody (1:200; Bioss). Slides were then incubated with the secondary antibody, visualized by $\mathrm{H}_{2} \mathrm{O}_{2}$-diaminobenzidine, counterstaind with hematoxylin and dehydrated. Moderate or strong cytoplasm staining was considered as positive reaction. The degree of immunocytochemical staining of specimens was evaluated by 3 independent pathologists.

\section{Western blot}

Cells were lysed in RIPA buffer. The protein concentration was determined by Bradford method. Equal amounts of cell extract were subjected to electrophoresis in SDS-polyacrylamide gel and transferred to nitrocellulose membrane (Millipore). Membranes were blocked and then incubated with GAPDH (Epitomics) or GLI1 (Biolegend) at $4^{\circ} \mathrm{C}$ overnight, followed by incubation for $1 \mathrm{~h}$ RT with appropriate secondary antibodies. Antibody binding was detected with an enhanced chemiluminescence kit.

\section{Flow cytometric staining}

For analyzing the purification of sorted cells, PE-conjugated CD34 antibody (BD Biosciences) was applied as recommended by the manufacturer. PE-conjugated CD11b antibody (Ebioscience) was used for cell differentiation detection. Expression of CD34 or CD11b on cell surface was measured by flow cytometry.

\section{Statistical analysis}

Unless otherwise indicated, all experiments were conducted in triplicate. Data were presented as means \pm SD. The patients were divided into 2 groups (GLI1-low and GLI1-high) based on the expression levels of GLI1 protein determined by western blot analysis. High expression of GLI1 was defined as the ratio of (GLI1 protein absorbance - background absorbance) versus (GAPDH absorbance - background absorbance) $\geq 0.50$. The comparison among characteristics of the groups were made using $\chi^{2}$ test for the binary variables, Pearson and Spearman correlation and linear regression analysis for the continuous variables. A value of $P<0.05$ was considered statistically significant. Statistics were calculated by GraphPad Prism software and SPSS software, version 13.0.

\section{Results}

GLI1 is overexpressed in CD34+ population enriched AML cell lines

Kasumi-1, KG1a, U937 and NB4 AML cells were stained with PE-conjugated CD34 antibody and subjected to flow cytometry analysis to determine the percentage of CD34 ${ }^{+}$ cells. The percentages of CD34+ cells were $98.2 \pm 0.43 \%$ in Kasumi- 1 cells, $96.6 \pm 0.65 \%$ in KG1a cells, but were hardly detectable in U937 and NB4 cells (Fig. 1A). We then examined mRNA expression of Hh signaling components, including GLI1, GLI2, GLI3, SMO and PTCH1 in these four cell lines. qRT-PCR analysis showed that high expression of GLI1 and SMO were observed in Kasumi-1 and KG1a cells when compared with U937 and NB4 cells (Fig. 1B). In addition, protein expression of GLI1 was correlated with the mRNA level (Fig. 1C). These results suggested that GLI1 might play an important role in leukemia progenitor cells. Since GLI1 is the ultimate activated transcription factor of Hh signaling, we further continued to investigate the role of GLI1 in AML and the effects of targeting GLI1. 


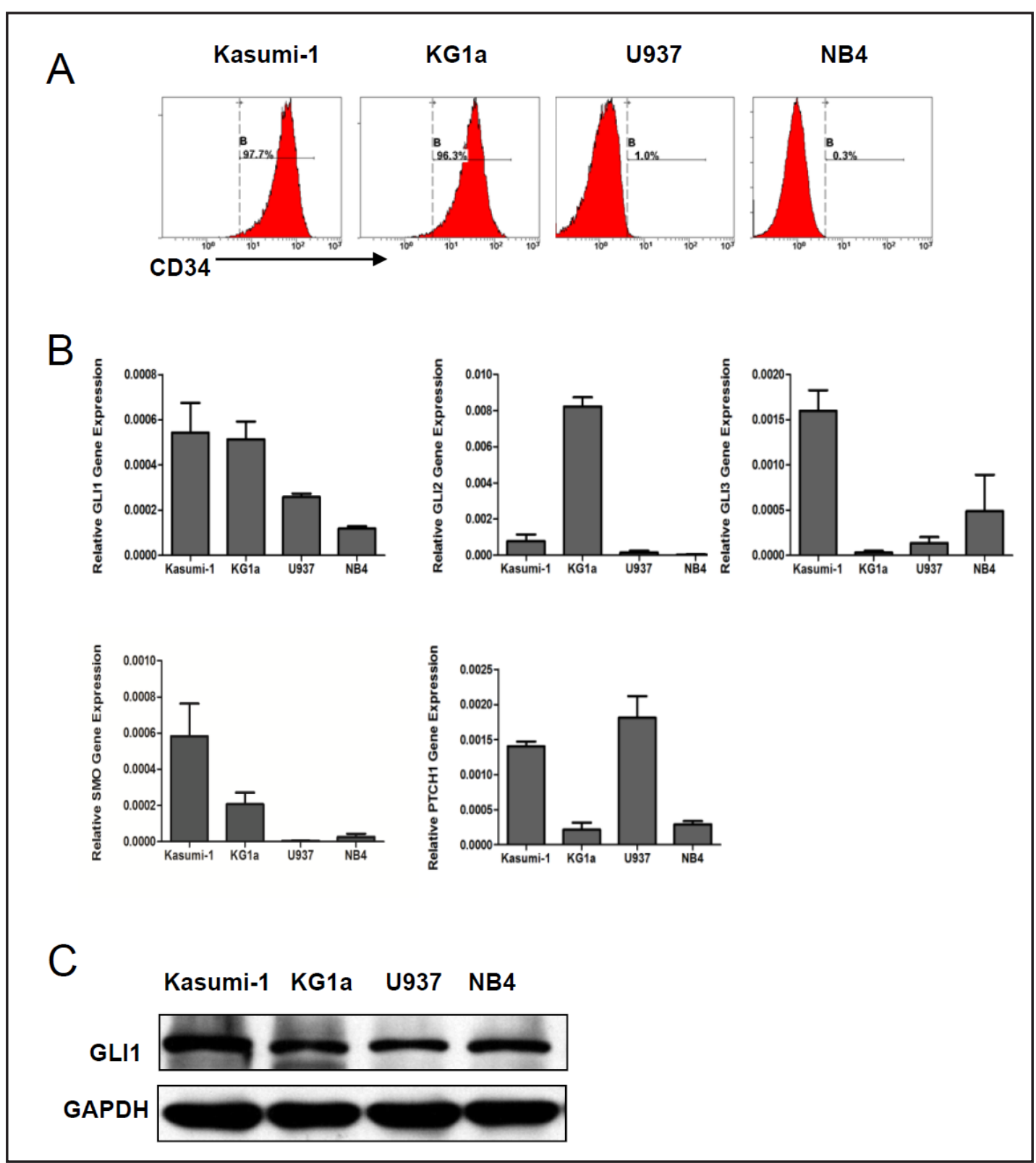

Fig. 1. The expression of GLI1 in AML cell lines. (A) Kasumi-1, KG1a, U937 and NB4 cells were stained with PE-conjugated CD34 antibody and subjected to flow cytometry analysis to determine the purity of CD34 ${ }^{+}$ cells. (B) Statistical data showed the expression of Hh signaling transcriptional factors GLI1, GLI2, GLI3, SMO and PTCH1 in AML cell lines using qRT-PCR analysis. (C) The protein expression of GLI1 in AML cell lines was analyzed by western blot.

GLI1 is overexpressed in primary AML samples and positively correlated with the ratio of CD34 $4^{+}$population

We next evaluated the expression of GLI1 in BMMCs from AML patients $(\mathrm{N}=40)$ and healthy donors $(\mathrm{N}=20)$. qRT-PCR analysis showed that the levels of GLI1 mRNA were 3.6fold higher in the samples derived from AML patients than that derived from healthy donors $(P<0.05$; Fig. 2A). We also verified expression of GLI1 protein in bone marrow specimens by immunocytochemical staining. The results showed that more positive staining of GLI1 
A
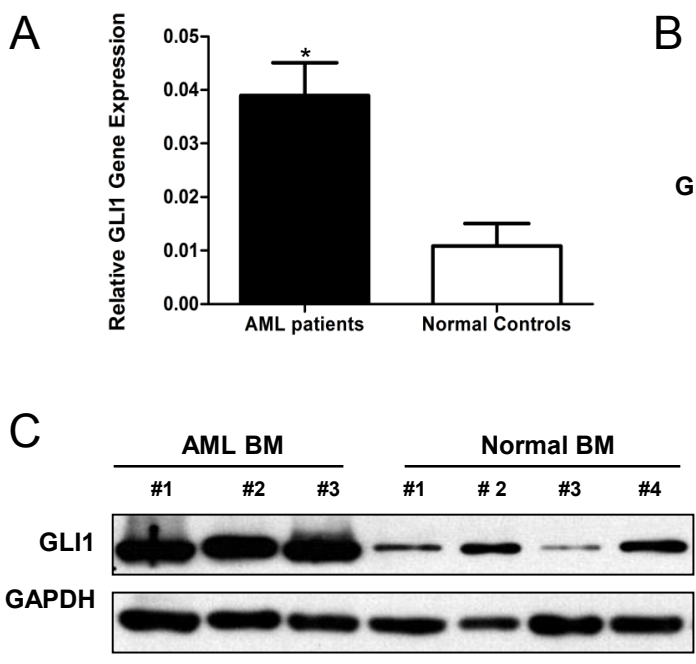

D

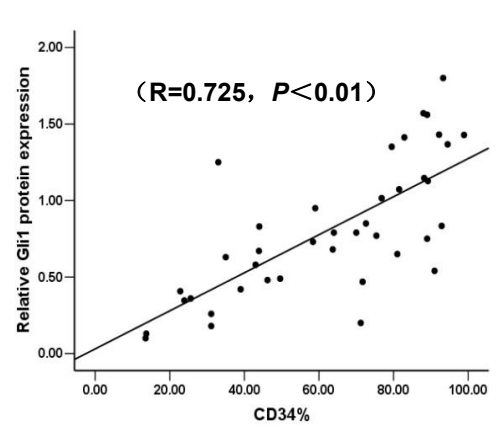

$B$

GLI1
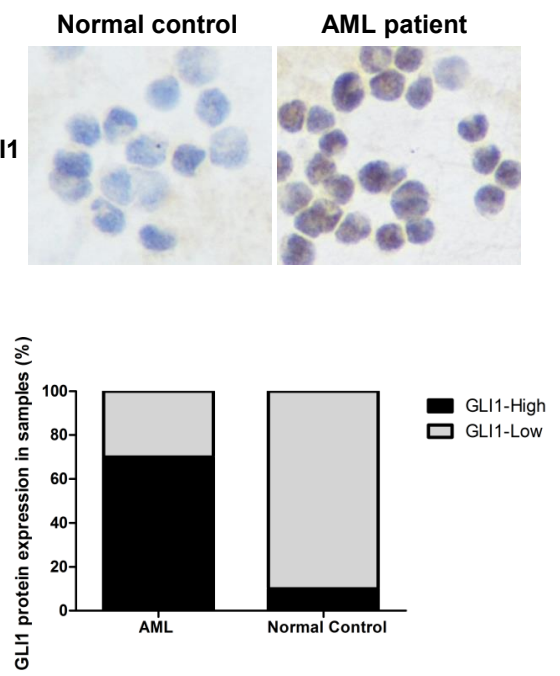

$E$

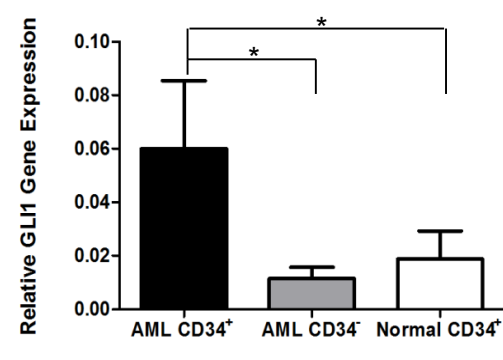

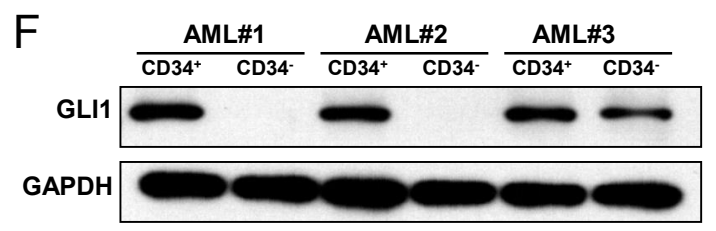

Fig. 2. The expression of GLI1 in primary AML samples. (A) Statistical data showed the expression of GLI1 mRNA determined by qRT-PCR in BMMCs from primary AML patients and normal controls. ${ }^{*} P<0.05$, compared with control. (B) BM samples were collected from AML patients and normal controls and subjected to immunocytochemical staining with antibody against GLI1 (original magnification, $\times 400$ ). (C) The expression levels of GLI1 protein in the representative AML samples and normal controls (left panel) were presented. Right panel showed the percentage of GLI1 high and GLI1 low expression samples in AML and normal controls. (D) The data showed the correlation between the GLI1 protein levels and the percentage of CD34 ${ }^{+}$ population in AML samples. (E) The bar graph showed the expression of GLI1 mRNA levels determined by qRT-PCR in AML CD34+ cells, AML CD34 cells and normal CD34+ cells. ${ }^{*} P<0.05$. (F) The expression of GLI1

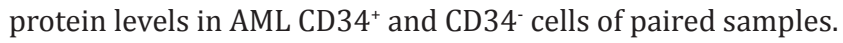

was presented in AML samples than normal controls (8/10 versus $1 / 10, P<0.05$; Fig. 2B), consistent with expression at the mRNA level. Similarly, GLI1 protein expression levels were evaluated by western blot analysis. As shown in Fig. 2C, 70\% of AML specimens displayed 


\begin{tabular}{|c|c|c|}
\hline Cellular Physiology & Cell Physiol Biochem 2016;38:1288-1302 & \\
\hline and Biochemistry & $\begin{array}{l}\text { Dol: 10.1159/000443075 } \\
\text { Published online: March 24, } 2016\end{array}$ & $\begin{array}{l}\text { O } 2016 \text { S. Karger AG, Basel } \\
\text { www.karger.com/cpb }\end{array}$ \\
\hline
\end{tabular}

Table 2. Relationship between GLI1 protein levels and clinical characteristics of AML cases. Abbreviations: BM, bone marrow; FAB, French-American-British classification; CR, complete response

\begin{tabular}{|c|c|c|c|c|}
\hline & \multicolumn{4}{|c|}{ GLI1 expression } \\
\hline & Total $\mathrm{N}=40$ & Low $\mathrm{N}=12$ & High $N=28$ & $P$ value \\
\hline \multicolumn{5}{|l|}{$\operatorname{Age}(y)$} \\
\hline median(range) & $38(14-71)$ & $46.1(15-71)$ & $34.7(14-67)$ & $P>0.05$ \\
\hline \multicolumn{5}{|l|}{ Sex } \\
\hline (male/female) & $25 / 15$ & $7 / 5$ & $17 / 11$ & $P>0.05$ \\
\hline \multicolumn{5}{|l|}{$\mathrm{WBC}\left(10^{\circ} \mathrm{L}-1\right)$} \\
\hline median(range) & 20.6 & $41.1(1.7-178.4)$ & $50.6(1.8-189.4)$ & $P>0.05$ \\
\hline \multicolumn{5}{|l|}{$\mathrm{HB}(\mathrm{g} / \mathrm{L})$} \\
\hline median(range) & 82 & $86.5(56-130)$ & $85.6(48-140)$ & $P>0.05$ \\
\hline \multicolumn{5}{|l|}{$\operatorname{PLT}\left(10^{\circ} \mathrm{L}-1\right)$} \\
\hline median(range) & 39.5 & $70.9(8-455)$ & $44.9(4-97)$ & $P>0.05$ \\
\hline \multicolumn{5}{|l|}{ BM blast } \\
\hline median(range) & 59.5 & $52.5(17-84)$ & $63.4(31-90)$ & $P>0.05$ \\
\hline \multicolumn{5}{|l|}{ CD34 (\%) } \\
\hline median(range) & 55.9 & $26.3(2.7-71.7)$ & $77.6(10.2-98.9)$ & $* P<0.01$ \\
\hline FAB classification & & & & $P>0.05$ \\
\hline M0 & 1 & 0 & 1 & \\
\hline M1 & 1 & 1 & 0 & \\
\hline M2 & 10 & 3 & 7 & \\
\hline M4 & 4 & 1 & 3 & \\
\hline M5 & 23 & 7 & 16 & \\
\hline M6 & 1 & 0 & 1 & \\
\hline FLT3-ITD & & & & $P>0.05$ \\
\hline FLT3-ITD-mut & 3 & 1 & 2 & \\
\hline FLT3-ITD-wt & 37 & 11 & 26 & \\
\hline Cytogenetics & & & & $P>0.05$ \\
\hline Favorable & 6 & 1 & 5 & \\
\hline Intermediate & 21 & 7 & 14 & \\
\hline Unfavorable & 13 & 4 & 9 & \\
\hline CR rate $[\%]$ & $72.5(29 / 40)$ & $75(9 / 12)$ & $71.4(20 / 28)$ & $P>0.05$ \\
\hline Relapse rate (\%) & $17.5(7 / 40)$ & $16.7(2 / 12)$ & $17.8(5 / 28)$ & $P>0.05$ \\
\hline
\end{tabular}

high expression of GLI1 protein, whereas $10 \%$ of normal controls showed high expression, indicating that the expression of GLI1 could be important for AML development. We next assessed the correlation between the expression of GLI1 protein and clinical variables. As shown in Table 2, GLI1 levels were positively correlated with the ratio of CD34+ progenitor population $(\mathrm{R}=0.725, P<0.01$; Fig. $2 \mathrm{D})$, but not significantly correlated with other clinical parameters.

To assess whether GLI1 was overexpressed in CD34+ AML progenitor cells, we measured the levels of GLI1 mRNA in $\mathrm{CD}^{+} 4^{+}$and CD34 cells isolated from the samples of 10 AML patients and 6 healthy donors. The expression of GLI1 mRNA in CD34+ AML progenitor cells were 3.2 and 5.3 fold higher than that in the CD34+ normal cells and CD34- AML cells, respectively (Fig. 2E). Western blot analysis showed that GLI1 protein was highly expressed in $\mathrm{CD}_{34}{ }^{+}$cells, compared with CD34 cells of paired AML samples (Fig. 2F). These results indicated that the expression of GLI1 could be critical for the maintenance of stemness in the AML progenitor cells.

GANT61 suppresses the growth of AML cells

We next examined the anti-leukemia effects of targeting GLI1. Kasumi-1, KG1a, U937 and NB4 cells were exposed to GANT61 $(0-100 \mu \mathrm{M})$ for $48 \mathrm{~h}$ and the cytotoxic effects were determined by WST-8 assay. Result showed that GANT61 induced a significant cytotoxic effect 
Fig. 3. GANT61 suppresses AML cell growth. (A) AML cell lines were treated with different concentrations of GANT61 for $48 \mathrm{~h}$. Cell viability was assessed by WST-8 assay. (B) The line graph showed the effect of GANT61 on colony formation capacity in AML cell lines. (C) AML cell lines were treated with different concentrations of vismodegib. The line graph showed the effect of vismodegib on colony formation capacity. ${ }^{*} P<0.05$, ** $P<0.01$, *** $P<$ 0.001 .
A
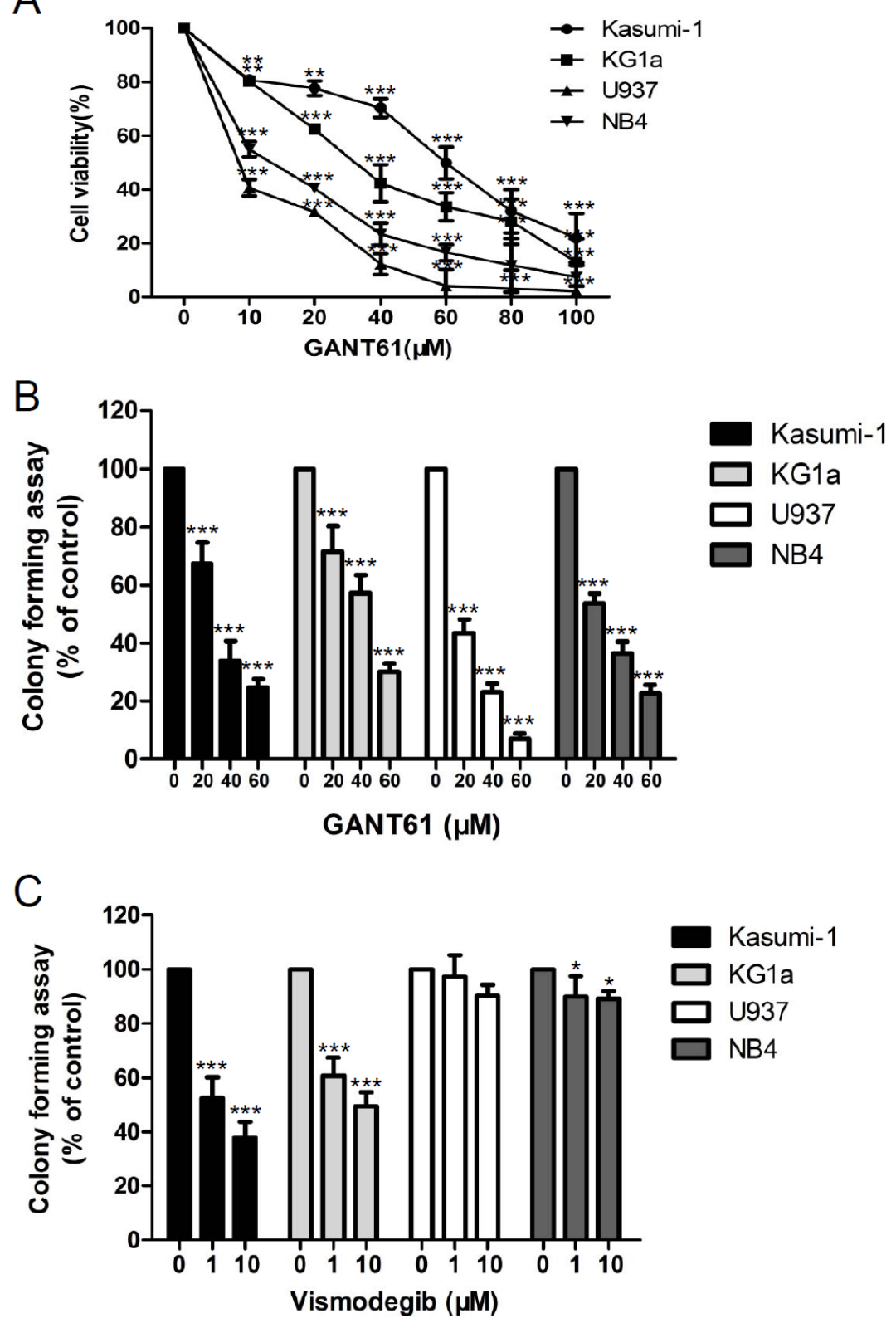

in all tested cell lines in a dose-dependent manner (Fig. 3A). The IC $_{50}$ values of GANT61 were $49.3 \pm 5.7,30.9 \pm 6.0,9.7 \pm 2.3$ and $13.2 \pm 2.8 \mu \mathrm{M}$ for Kasumi-1, KG1a, U937 and NB4 cells, respectively. The anti-proliferative effects of GANT61 were further determined by colony formation assay for 14 days. As shown in Fig. 3B, treatment with $20 \mu \mathrm{M}$ GANT61 resulted in a reduction in colony formation to $67.5 \pm 7.2 \%, 71.5 \pm 8.9 \%, 43.5 \pm 4.8 \%$ and $53.7 \pm 3.4 \%$ in Kasumi-1, KG1a, U937 and NB4 cells, further supporting an anti-proliferative effects of GANT61 on AML cell lines. We also tested the effects of the SMO antagonist, vismodegib, on AML cells. The colony formation capacities were significantly reduced in Kasumi-1 and KG1a cells compared to U937 and NB4 cells after treatment with $1 \mu \mathrm{M}$ vismodegib (Fig. 3C).

GANT61 induces apoptosis in Kasumi-1 and KG1a cells

To determine if the inhibition of growth induced by GANT61 in AML cells was caused by induction of apoptosis, we examined apoptosis by detecting Annexin V/PI expression and 
A

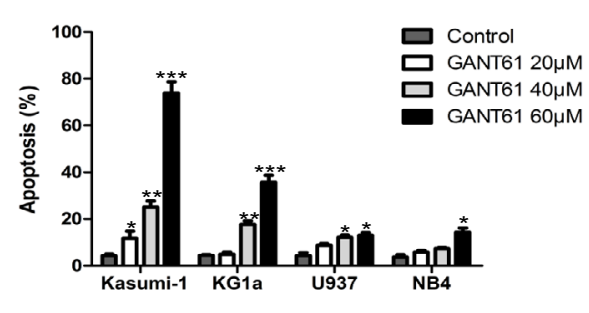

C

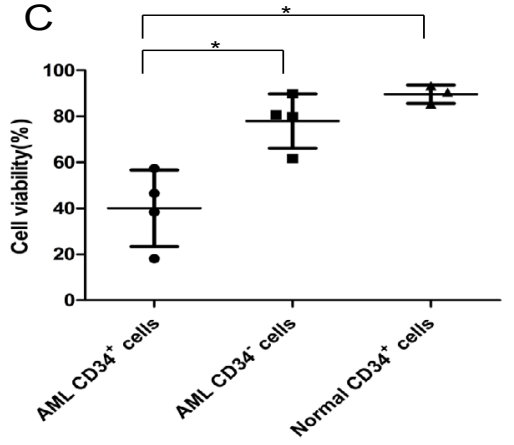

B

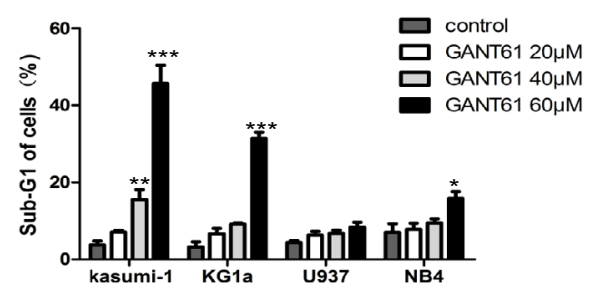

D

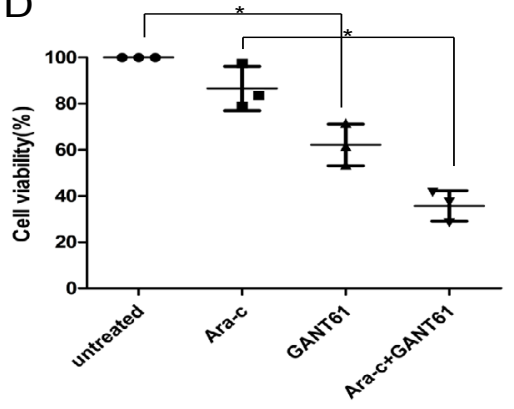

Fig. 4. GANT61 promotes apoptosis and enhances chemosensitivity in CD34+ enriched AML cells. (A) AML cell lines were stained with AnnexinV/PI to analyze apoptotic cell populations after treatment with GANT61 for $48 \mathrm{~h}$. The data were presented as the means \pm SD of three independent experiments. (B) The proportion of sub-G1 cells after treating with GANT 61 for $48 \mathrm{~h}$ was assessed by FACS analysis. (C) CD34+ and CD34 cells derived from 4 AML samples and $\mathrm{CD}_{3} 4^{+}$cells derived from 3 normal samples were incubated with $60 \mu \mathrm{M}$ GANT61 for $48 \mathrm{~h}$. Cell viability was assessed by WST-8 assay. (D) CD34+ cells derived from 3 AML samples were incubated with Ara-c $(0.01 \mu \mathrm{M})$, GANT61 $(40 \mu \mathrm{M})$ or combination. Cell viability was assessed by WST-8 assay. ${ }^{*} P<0.05,{ }^{* *} P<0.01,{ }^{* * *} P<0.001$.

sub-G1 population. Treatment with $60 \mu \mathrm{M}$ GANT61 for $48 \mathrm{~h}$, the rates of apoptosis were 73.9 $\pm 8.4 \%, 35.7 \pm 5.5 \%, 12.9 \pm 2.1 \%$ and $14.4 \pm 3.0 \%$ in Kasumi- 1, KG1a, U937 and NB4 cells, respectively (Fig. 4A). Consistently, incubation with $60 \mu \mathrm{M}$ GANT61 led to a significantly increased sub-G1 population in Kasumi-1 and KG1a cells $(45.8 \pm 4.7 \%$ and $31.5 \pm 1.6 \%$ respectively; Fig. 4B), but induced a mild cell death in U937 and NB4 cells ( $8.3 \pm 1.4 \%$ and $15.9 \pm 1.7 \%$ respectively). These findings suggested that $\mathrm{CD} 34^{+}$population could be sensitive to GLI1 inhibition and subsequently underwent apoptosis.

Due to the resistance of CD34+ enriched AML cell lines to chemotherapeutics and the high expression of GLI1 in CD34+ enriched AML cell lines, we sought to determine whether GANT61 may increase the drug sensitivity. The CD34 ${ }^{+}$and CD34 populations were sorted from BMMCs from 4 AML patients and 3 healthy donors. After incubation with $60 \mu \mathrm{M}$ GANT 61 for $48 \mathrm{~h}$, the survival was analyzed by WST- 8 assay. The results showed that the CD34+ primary AML cells were more sensitive to GANT61 compared with the other groups (the survival rate of CD34 $4^{+}$AML cells was $40.1 \pm 16.6 \%$, while CD34- AML cells was $78.1 \pm 11.8 \%$ and CD34 ${ }^{+}$ normal cells was $89.7 \pm 4.0 \%$, Fig. $4 \mathrm{C}$ ). We further examined the combinational effect of Ara-C and GANT61. As shown in Fig. 4D, combinational effect of Ara-C and GANT61 induced a significantly reduction of cell survival compared with each agents alone (the survival rate of Ara-c alone was $86.7 \pm 9.6 \%$, while GANT61 alone was $62.2 \pm 9.1 \%$, and the combination of Ara-c and GANT61 was $35.8 \pm 6.7 \%$ ).

GANT61 induces differentiation in U937 and NB4 cells

Given that GANT61 markedly suppressed proliferation but caused minimal apoptosis in U937 and NB4 cells, we next investigated the effect of GANT61 on differentiation capacity 
Fig. 5. GANT61 induces differentiation in CD34 population enriched U937 and NB4 cells. (A) Expression of $\mathrm{CD} 11 \mathrm{~b}$ was analyzed by FACS in AML cells incubated with ATRA and/or GANT61 for 4 days. (B) Cell morphology of Kasumi-1 and U937 cells was analyzed by Wright-Giemsa staining after treatment with ATRA and/ or GANT61 for 4 days (upper panel). Quantitative analysis of the cells with lobulation was performed under a microscope and the data were presented as the means \pm SD of three independent experiments (lower panel). ${ }^{*} P<0.05$, ** $P$ $<0.01$, ${ }^{* * *} P<0.001$.

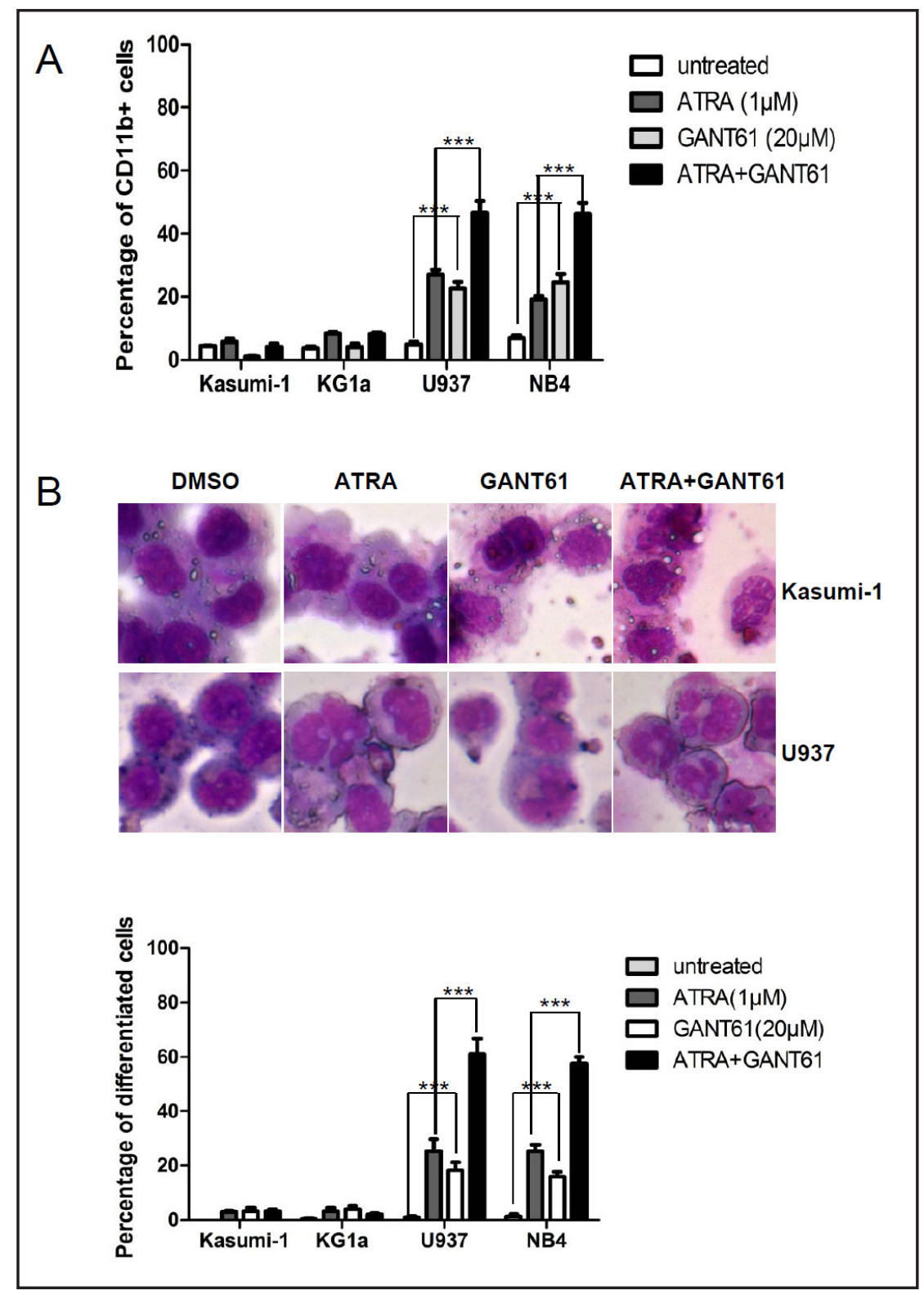

in these cells. The expression of myeloid differentiation marker CD11b, was analyzed for AML cells after treatment with all-trans-retinoic acid (ATRA) and/or GANT61. The percentage of cells expressing CD11b were increased by 5.5-fold and 3.6-fold in U937 and NB4 cells respectively after treatment with $20 \mu \mathrm{M}$ GANT61 compared with control (Fig. 5A). Furthermore, combination of ATRA and GANT 61 increased the fraction of CD11 $\mathrm{b}^{+}$cells by 2.1fold and by 2.4-fold in U937 and NB4 cells compared with treatment with ATRA alone (Fig. 5A). Interestingly, treatment with ATRA and GANT61 resulted in minimal differentiation in Kasumi-1 and KG1a cells (Fig. 5A). Cyto-morphological evaluation also showed an increased percentage of cells with nuclear lobulation in U937 and NB4 cells, but not in Kasumi-1 and KG1a cells (Fig. 5B). Cells with lobulation were counted under a microscope and the data was shown in Fig. 5B. Taken together, our findings showed that GANT61 induced myeloid differentiation in U937 and NB4 cells which contained less CD34+ population.

Knockdown of GLI1 reduces cell viability and induces apoptosis in AML cells

We next suppressed the expression of GLI1 by shRNA in Kasumi-1 and U937 cells, as detected by western blot analysis (Fig. 6A). Knockdown of endogenous GLI1 protein resulted 
Fig. 6. Knockdown of GLI1 reduces cell viability and induces apoptosis in AML cells. (A) Kasumi-1 and U937 cells were infected with GLI1 shRNA or control lentivirus for $48 \mathrm{~h}$ and subjected to western blot for GLI1 expression. (B) Cell viability was assessed by WST-8 assay. (C) AnnexinV/PI analysis was performed in Kasumi-1 and U937 cells after infected with GLI1 shRNA or control lentivirus for 48 h. ${ }^{*} P<0.05$.

in a reduction in cell viability in both Kasumi-1 and U937 cells (Fig. 6B). In addition, suppression of GLI1 for $48 \mathrm{~h}$ resulted in apoptotic death. The rates of apoptosis were $24.6 \pm 5.2 \%$ and 16.9 $\pm 2.8 \%$ in Kasumi-1 and U937 cells, respectively (Fig. 6C), similar to that in GANT61-treated AML cells. These results indicated that suppression of GLI1 was indeed critical for GANT61induced anti-leukemia effect in AML cells.

\section{Discussion}

In the present study, we found that GLI1 was highly expressed in CD34+ enriched Kasumi-1 and KG1a cells, compared with U937 and NB4 cells (Fig. 1B and C). Similar phenomena were confirmed using the samples derived from AML patients and the healthy donors (Fig. 2A, B and C). Moreover, our data showed that targeting GLI1 by GANT61 significantly inhibited AML cells growth (Fig. 3A and B). Interestingly, the decreased growth induced by GANT61 was caused by different mechanisms, which could be dependent on the CD34 expression (Fig. 4A and Fig. 5B). Finally, our data showed that inhibition of GLI1 significantly enhanced the sensitivity to traditional anti-leukemic drug, including Ara-C and ATRA (Fig. 4D and Fig. 5A). These findings indicated that GLI1 could be a promising target for AML therapy.

The Hh signaling leads to activation of GLI, which transcriptionally regulates various target genes. The precise control of Hh signaling activity is critical during embryogenesis, while aberrantly activated Hh signaling contributes to the development of various human malignancies [32]. The GLI family of transcription factors regulates the expression of target gene that determines the Hh-dependent survival. GLI1 and GLI2 are the activators of Hh signaling, and constitutive activation of at least one of them is critical for cancer development [25]. Recent studies reported a correlation between expression levels of GLI1 in tumor samples with disease progression and poor clinical outcome [33, 34]. Higher GLI1 expression predicted a worse survival in AML [35]. In this study, we found that GLI1 was overexpressed in BMMCs in a significant proportion of de novo AML patients (Fig. 2A, B and C). This finding supported the role of GLI1 in cell proliferation and survival and suggested potential involvement of $\mathrm{Hh}$ signaling in the pathogenesis of AML.

Emerging data demonstrated a specific involvement of Hh signaling in hematologic malignancies [19, 20, 36, 37]. It was reported that overexpression of the genes in $\mathrm{Hh}$ pathway during progenitor cell expansion was associated with malignant transformation 


\section{Cellular Physiology Cell Physiol Biochem 2016;38:1288-1302 \begin{tabular}{ll|l}
\cline { 2 - 2 } and Bioch 10.1159/000443075 & $\begin{array}{l}\text { O 2016 S. Karger AG, Basel } \\
\text { www.karger.com/cpb }\end{array}$ \\
\hline $\begin{array}{ll}\text { Published online: March 24, 2016 } & \end{array}$
\end{tabular}}

Long et al.: GANT61 Enhances Chemosensitivity in AML

in $\mathrm{CD}_{133^{+}} / \mathrm{CD}^{4} 4^{+}$cells [38]. In MM, Hh pathway activation promoted the expansion of CSCs whereas inhibition of Hh pathway resulted in terminal differentiation, loss of self-renewal, and exhaustion of the malignant clone [18]. Furthermore, the genes in Hh pathway, such as GLI1, PTCH1 and SMO, were significantly upregulated in BCR/ABL-positive LSCs [39]. We found that GLI1 was overexpressed in Kasumi-1 and KG1a cells that contained more $\mathrm{CD}_{3}{ }^{+}$population, and that GLI1 levels were also significantly higher in primary CD34 ${ }^{+} \mathrm{AML}$ cells than CD34- AML cells and CD34+ normal cells (Fig. 2E and F). Importantly, GLI1 protein expression was positively correlated with the ratio of $\mathrm{CD}_{3} 4^{+}$population in BMMCs of AML samples (Fig. 2D). These studies suggested that activation of Hh signaling in progenitor cells might confer LSCs survival and self-renewal advantages and contribute to disease relapse. Thus, strategies selectively targeting Hh signaling might efficiently eradicate LSCs and prevent the recurrence of the disease.

Due to the potential important role of Hh signaling in cancer, the development of strategies targeting the Hh signaling has attracted a number of attentions. Recently, the major targeting points for Hh signaling inhibitors were Shh neutralizing antibodies, SMO protein inhibitors (such as cyclopamine and GDC-0449) and GLI protein inhibitors (such as HPI-1 and GANT61) [40]. In this study, we found that GANT61 effectively inhibited the growth of AML cell lines (Fig. 3A and B), suggesting that targeting the GLI transcription factors efficiently suppressed AML growth.

We further showed that GANT61 induced apoptosis in Kasumi-1 and KG1a cells in a dose-dependent manner, but only caused minimal apoptosis in U937 and NB4 cells (Fig. 4A and B). Interestingly, treatment with GANT61 stimulated the expression of CD11b antigen and nuclear lobulation in U937 and NB4 cells but not in Kasumi-1 and KG1a cells (Fig. 5A and B), suggesting that GANT61 induced different anti-cancer effects in stem cells and non-stem cells population. A recent study reported that inhibition of Hh signalling induced apoptosis by decreasing c-myc, cyclin D1 and Bcl-2 protein expression, ERK and JNK phosphorylation, and increasing Caspase-3 cleavage in OPM1 MM cells [14]. Moreover, inhibition of $\mathrm{Hh}$ signaling suppressed clonogenic growth of NCI-H929 MM cells by inducing terminal plasma cells differentiation rather than cytotoxicity [18]. Therefore, different molecular mechanisms might account for the pro-apoptosis or pro-differentiation effects induced by GANT61 in cancer cells.

Increasing evidence indicates that Hh signaling is critical for maintaining the stemness of CSCs, which are generally insensitive to chemotherapy $[37,41,42]$. Hh signaling regulates expression of CSC-related markers, such as aldehyde dehydrogenase, Bmi1, snail, Wnt2, PDGFR $\alpha$, jagged-1, CD44, and c-MET [43-46]. Moreover, functional studies have indicated that the putative CSCs, such as $\mathrm{CD} 133^{+}$population in Glioma and colon cancer cells, $\mathrm{CD} 44^{+} \mathrm{CD} 24$ population in breast cancer cells, $\mathrm{ALDH}^{+}$population in pancreatic cancer cells and BCR/ABL positive population in CML cells, were sensitive to pharmacological inhibition of the Hh pathway $[39,46-49]$. Our data showed that primary CD34+ AML cells underwent proliferation inhibition by treating with GANT61, while minimal toxicity has been observed in $\mathrm{CD}_{3} 4^{+}$normal cells (Fig. 4C). Thus, our results suggested a specific anti-leukemia activity and a favorable therapeutic application of GANT61.

The current available data provide a rationale for using GANT61 as adjuvant therapeutic agents to increase the sensitivity to current chemotherapeutic agents. A study revealed that the combination of GANT61 with vincristine reversed chemoresistance in Lucena-1 cells [17]. Another study showed that treatment with GANT61 and rapamycin produced a synergistic anti-proliferative effect on myeloid leukemic cells [50]. Consistently, our results showed that GANT61 significantly enhanced the cytotoxic effects of Ara-c in primary CD34+ AML cells (Fig. 4D), indicating that GANT61 could potentiate the efficacy of chemotherapeutic drugs.

In summary, we showed that GLI1 was overexpressed in AML progenitor cells. Targeting GLI1 by GANT61 potently inhibited the growth of the AML CD34+ ${ }^{+}$cell fraction and enhanced the sensitivity to Ara-C. Taken together, our results suggested that GLI1 was a promising therapeutic target for AML.

\section{KARGER}




\begin{tabular}{|c|c|c|}
\hline Cellular Physiology & Cell Physiol Biochem 2016;38:1288-1302 & \\
\hline and Biochemistry & \begin{tabular}{l|} 
DOI: $10.1159 / 000443075$ \\
Published online: March 24, 2016 \\
\end{tabular} & $\begin{array}{l}\text { O } 2016 \text { S. Karger AG, Basel } \\
\text { www.karger.com/cpb }\end{array}$ \\
\hline
\end{tabular}

Long et al.: GANT61 Enhances Chemosensitivity in AML

\section{Abbreviations}

AML (Acute myeloid leukemia); Hh (Hedgehog); PTCH (Patched); SMO (Smoothened); Ara-c (Cytarabine); MM (Multiple myeloma); CSC (Cancer stem cell); LSC (Leukemia stem cell); BMMC (Bone marrow mononuclear cell); ATRA (All-trans-retinoic acid); CLL (Chronic lymphocytic leukemia); CML (Chronic myeloid leukemia).

\section{Acknowledgements}

We thank the members of Quentin Liu lab for their critical comments and technical support. This work was supported by the National Natural Science Foundation of China (No. 81130040 to Q. Liu), the Science and Technology Planning Project of Guangdong Province (No. 2013B021800089 to Z.-J. Long, No. 2013B021800087 to Q. Liu, No. 2015A030310050 to B. Long, No. 2013B021800127 to X.-Z. Tong) and the Medical Scientific Research Foundation of Guangdong (No. B2012115 to Y. Hu).

\section{Disclosure Statement}

The authors declare no conflict of interest.

\section{References}

1 Marcucci G, Haferlach T, Dohner H: Molecular genetics of adult acute myeloid leukemia: Prognostic and therapeutic implications. J Clin Oncol 2011;29:475-486.

2 Krug U, Rollig C, Koschmieder A, Heinecke A, Sauerland MC, Schaich M, Thiede C, Kramer M, Braess J, Spiekermann K, Haferlach T, Haferlach C, Koschmieder S, Rohde C, Serve H, Wormann B, Hiddemann W, Ehninger G, Berdel WE, Buchner T, Muller-Tidow C: Complete remission and early death after intensive chemotherapy in patients aged 60 years or older with acute myeloid leukaemia: A web-based application for prediction of outcomes. Lancet 2010;376:2000-2008.

3 Gentles AJ, Plevritis SK, Majeti R, Alizadeh AA: Association of a leukemic stem cell gene expression signature with clinical outcomes in acute myeloid leukemia. Jama 2010;304:2706-2715.

4 Eppert K, Takenaka K, Lechman ER, Waldron L, Nilsson B, van Galen P, Metzeler KH, Poeppl A, Ling V, Beyene J, Canty AJ, Danska JS, Bohlander SK, Buske C, Minden MD, Golub TR, Jurisica I, Ebert BL, Dick JE: Stem cell gene expression programs influence clinical outcome in human leukemia. Nat Med 2011;17:1086-1093.

$5 \quad$ Nusslein-Volhard C, Wieschaus E: Mutations affecting segment number and polarity in drosophila. Nature 1980;287:795-801.

6 Ingham PW, McMahon AP: Hedgehog signaling in animal development: Paradigms and principles. Genes Dev 2001;15:3059-3087.

7 Chen JK, Taipale J, Cooper MK, Beachy PA: Inhibition of hedgehog signaling by direct binding of cyclopamine to smoothened. Genes Dev 2002;16:2743-2748.

8 Duman-Scheel M, Weng L, Xin S, Du W: Hedgehog regulates cell growth and proliferation by inducing cyclin d and cyclin e. Nature 2002;417:299-304.

9 Lum L, Beachy PA: The hedgehog response network: Sensors, switches, and routers. Science 2004;304:1755-1759.

10 Taipale J, Chen JK, Cooper MK, Wang B, Mann RK, Milenkovic L, Scott MP, Beachy PA: Effects of oncogenic mutations in smoothened and patched can be reversed by cyclopamine. Nature 2000;406:1005-1009.

11 Lee J, Platt KA, Censullo P, Ruiz i Altaba A: Gli1 is a target of sonic hedgehog that induces ventral neural tube development. Development 1997;124:2537-2552.

12 Robbins DJ, Hebrok M: Hedgehogs: La dolce vita. Workshop on hedgehog-gli signaling in cancer and stem cells. EMBO Rep 2007;8:451-455. 
13 Yoon JW, Gallant M, Lamm ML, Iannaccone S, Vieux KF, Proytcheva M, Hyjek E, Iannaccone P, Walterhouse D: Noncanonical regulation of the hedgehog mediator gli1 by c-myc in burkitt lymphoma. Mol Cancer Res 2013;11:604-615.

14 Blotta S, Jakubikova J, Calimeri T, Roccaro AM, Amodio N, Azab AK, Foresta U, Mitsiades CS, Rossi M, Todoerti K, Molica S, Morabito F, Neri A, Tagliaferri P, Tassone P, Anderson KC, Munshi NC: Canonical and noncanonical hedgehog pathway in the pathogenesis of multiple myeloma. Blood 2012;120:5002-5013.

15 Singh RR, Kim JE, Davuluri Y, Drakos E, Cho-Vega JH, Amin HM, Vega F: Hedgehog signaling pathway is activated in diffuse large b-cell lymphoma and contributes to tumor cell survival and proliferation. Leukemia 2010;24:1025-1036.

16 Singh RR, Kunkalla K, Qu C, Schlette E, Neelapu SS, Samaniego F, Vega F: Abcg2 is a direct transcriptional target of hedgehog signaling and involved in stroma-induced drug tolerance in diffuse large b-cell lymphoma. Oncogene 2011;30:4874-4886.

17 Queiroz KC, Ruela-de-Sousa RR, Fuhler GM, Aberson HL, Ferreira CV, Peppelenbosch MP, Spek CA: Hedgehog signaling maintains chemoresistance in myeloid leukemic cells. Oncogene 2010;29:6314-6322.

18 Peacock CD, Wang Q Gesell GS, Corcoran-Schwartz IM, Jones E, Kim J, Devereux WL, Rhodes JT, Huff CA, Beachy PA, Watkins DN, Matsui W: Hedgehog signaling maintains a tumor stem cell compartment in multiple myeloma. Proc Natl Acad Sci USA 2007;104:4048-4053.

19 Zhao C, Chen A, Jamieson CH, Fereshteh M, Abrahamsson A, Blum J, Kwon HY, Kim J, Chute JP, Rizzieri D, Munchhof M, VanArsdale T, Beachy PA, Reya T: Hedgehog signalling is essential for maintenance of cancer stem cells in myeloid leukaemia. Nature 2009;458:776-779.

20 Dierks C, Beigi R, Guo GR, Zirlik K, Stegert MR, Manley P, Trussell C, Schmitt-Graeff A, Landwerlin K, Veelken H, Warmuth M: Expansion of bcr-abl-positive leukemic stem cells is dependent on hedgehog pathway activation. Cancer Cell 2008;14:238-249.

21 Kobune M, Takimoto R, Murase K, Iyama S, Sato T, Kikuchi S, Kawano Y, Miyanishi K, Sato Y, Niitsu Y, Kato J: Drug resistance is dramatically restored by hedgehog inhibitors in cd34+ leukemic cells. Cancer Sci 2009;100:948-955.

22 Dijkgraaf GJ, Alicke B, Weinmann L, Januario T, West K, Modrusan Z, Burdick D, Goldsmith R, Robarge K, Sutherlin D, Scales SJ, Gould SE, Yauch RL, de Sauvage FJ: Small molecule inhibition of gdc-0449 refractory smoothened mutants and downstream mechanisms of drug resistance. Cancer Res 2011;71:435-444.

23 Buonamici S, Williams J, Morrissey M, Wang A, Guo R, Vattay A, Hsiao K, Yuan J, Green J, Ospina B, Yu Q, Ostrom L, Fordjour P, Anderson DL, Monahan JE, Kelleher JF, Peukert S, Pan S, Wu X, Maira SM, GarciaEcheverria C, Briggs KJ, Watkins DN, Yao YM, Lengauer C, Warmuth M, Sellers WR, Dorsch M: Interfering with resistance to smoothened antagonists by inhibition of the pi3k pathway in medulloblastoma. Sci Transl Med 2010;2:51ra70.

24 Taylor MD, Liu L, Raffel C, Hui CC, Mainprize TG, Zhang X, Agatep R, Chiappa S, Gao L, Lowrance A, Hao A, Goldstein AM, Stavrou T, Scherer SW, Dura WT, Wainwright B, Squire JA, Rutka JT, Hogg D: Mutations in sufu predispose to medulloblastoma. Nat Genet 2002;31:306-310.

25 Lauth M, Bergstrom A, Shimokawa T, Toftgard R: Inhibition of gli-mediated transcription and tumor cell growth by small-molecule antagonists. Proc Natl Acad Sci USA 2007;104:8455-8460.

26 Wickstrom M, Dyberg C, Shimokawa T, Milosevic J, Baryawno N, Fuskevag OM, Larsson R, Kogner P, Zaphiropoulos PG, Johnsen JI: Targeting the hedgehog signal transduction pathway at the level of gli inhibits neuroblastoma cell growth in vitro and in vivo. Int J Cancer 2013;132:1516-1524.

27 Mazumdar T, Devecchio J, Agyeman A, Shi T, Houghton JA: Blocking hedgehog survival signaling at the level of the gli genes induces DNA damage and extensive cell death in human colon carcinoma cells. Cancer Res 2011;71:5904-5914.

28 Desch P, Asslaber D, Kern D, Schnidar H, Mangelberger D, Alinger B, Stoecher M, Hofbauer SW, Neureiter D, Tinhofer I, Aberger F, Hartmann TN, Greil R: Inhibition of gli, but not smoothened, induces apoptosis in chronic lymphocytic leukemia cells. Oncogene 2010;29:4885-4895.

29 Asou H, Tashiro S, Hamamoto K, Otsuji A, Kita K, Kamada N: Establishment of a human acute myeloid leukemia cell line (kasumi-1) with 8;21 chromosome translocation. Blood 1991;77:2031-2036.

30 Koeffler HP, Billing R, Lusis AJ, Sparkes R, Golde DW: An undifferentiated variant derived from the human acute myelogenous leukemia cell line (kg-1). Blood 1980;56:265-273. 
31 Wu X, Yang N, Zhou WH, Xu J, Chen JJ, Zheng FM, Long ZJ, Yue CF, Ai KX, Liu LL, Wan XY, Liu Q: Up-regulation of p21 inhibits trail-mediated extrinsic apoptosis, contributing resistance to saha in acute myeloid leukemia cells. Cell Physiol Biochem 2014;34:506-518.

32 Jiang J, Hui CC: Hedgehog signaling in development and cancer. Dev Cell 2008;15:801-812.

33 Hegde GV, Peterson KJ, Emanuel K, Mittal AK, Joshi AD, Dickinson JD, Kollessery GJ, Bociek RG, Bierman P, Vose JM, Weisenburger DD, Joshi SS: Hedgehog-induced survival of b-cell chronic lymphocytic leukemia cells in a stromal cell microenvironment: A potential new therapeutic target. Mol Cancer Res 2008;6:19281936.

34 Ciucci A, De Stefano I, Vellone VG, Lisi L, Bottoni C, Scambia G, Zannoni GF, Gallo D: Expression of the glioma-associated oncogene homolog 1 (gli1) in advanced serous ovarian cancer is associated with unfavorable overall survival. PLoS One 2013;8:e60145.

35 Zahreddine HA, Culjkovic-Kraljacic B, Assouline S, Gendron P, Romeo AA, Morris SJ, Cormack G, Jaquith JB, Cerchietti L, Cocolakis E, Amri A, Bergeron J, Leber B, Becker MW, Pei S, Jordan CT, Miller WH, Borden KL: The sonic hedgehog factor gli1 imparts drug resistance through inducible glucuronidation. Nature 2014;511:90-93.

36 Ji Z, Mei FC, Johnson BH, Thompson EB, Cheng X: Protein kinase a, not epac, suppresses hedgehog activity and regulates glucocorticoid sensitivity in acute lymphoblastic leukemia cells. J Biol Chem 2007;282:37370-37377.

37 Lin TL, Wang QH, Brown P, Peacock C, Merchant AA, Brennan S, Jones E, McGovern K, Watkins DN, Sakamoto KM, Matsui W: Self-renewal of acute lymphocytic leukemia cells is limited by the hedgehog pathway inhibitors cyclopamine and ipi-926. PLoS One 2010;5:e15262.

38 Okamoto OK, Carvalho AC, Marti LC, Vencio RZ, Moreira-Filho CA: Common molecular pathways involved in human cd133+/cd34+ progenitor cell expansion and cancer. Cancer Cell Int 2007;7:11.

39 Jagani Z, Dorsch M, Warmuth M: Hedgehog pathway activation in chronic myeloid leukemia. Cell Cycle 2010;9:3449-3456.

40 Yang L, Xie G, Fan Q Xie J: Activation of the hedgehog-signaling pathway in human cancer and the clinical implications. Oncogene 2010;29:469-481.

41 Clevers H: The cancer stem cell: Premises, promises and challenges. Nat Med 2011;17:313-319.

42 Magee JA, Piskounova E, Morrison SJ: Cancer stem cells: Impact, heterogeneity, and uncertainty. Cancer Cell 2012;21:283-296.

43 Joost S, Almada LL, Rohnalter V, Holz PS, Vrabel AM, Fernandez-Barrena MG, McWilliams RR, Krause M, Fernandez-Zapico ME, Lauth M: Gli1 inhibition promotes epithelial-to-mesenchymal transition in pancreatic cancer cells. Cancer Res 2012;72:88-99.

44 Takebe N, Harris PJ, Warren RQ Ivy SP: Targeting cancer stem cells by inhibiting wnt, notch, and hedgehog pathways. Nat Rev Clin Oncol 2011;8:97-106.

45 Tanaka H, Nakamura M, Kameda C, Kubo M, Sato N, Kuroki S, Tanaka M, Katano M: The hedgehog signaling pathway plays an essential role in maintaining the cd44+cd24-/low subpopulation and the side population of breast cancer cells. Anticancer Res 2009;29:2147-2157.

46 Liu S, Dontu G, Mantle ID, Patel S, Ahn NS, Jackson KW, Suri P, Wicha MS: Hedgehog signaling and bmi-1 regulate self-renewal of normal and malignant human mammary stem cells. Cancer Res 2006;66:60636071.

47 Varnat F, Duquet A, Malerba M, Zbinden M, Mas C, Gervaz P, Ruiz i Altaba A: Human colon cancer epithelial cells harbour active hedgehog-gli signalling that is essential for tumour growth, recurrence, metastasis and stem cell survival and expansion. EMBO Mol Med 2009;1:338-351.

48 Feldmann G, Fendrich V, McGovern K, Bedja D, Bisht S, Alvarez H, Koorstra JB, Habbe N, Karikari C, Mullendore M, Gabrielson KL, Sharma R, Matsui W, Maitra A: An orally bioavailable small-molecule inhibitor of hedgehog signaling inhibits tumor initiation and metastasis in pancreatic cancer. Mol Cancer Ther 2008;7:2725-2735.

49 Bar EE, Chaudhry A, Lin A, Fan X, Schreck K, Matsui W, Piccirillo S, Vescovi AL, DiMeco F, Olivi A, Eberhart CG: Cyclopamine-mediated hedgehog pathway inhibition depletes stem-like cancer cells in glioblastoma. Stem Cells 2007;25:2524-2533.

50 Pan D, Li Y, Li Z, Wang Y, Wang P, Liang Y: Gli inhibitor gant61 causes apoptosis in myeloid leukemia cells and acts in synergy with rapamycin. Leuk Res 2012;36:742-748. 